\title{
EXPERIMENTAL AND ANALYTICAL STUDY OF THE INTER-STOREY HOLD-DOWN CONNECTIONS IN TIMBER-FRAME PANEL BUILDINGS
}

\author{
Katja Vogrinec ${ }^{1^{*}}$, Miroslav Premrov ${ }^{2}$ \\ ${ }^{1}$ Masiv DOO, Gornja Radgona, Slovenia \\ ${ }^{2}$ University of Maribor, Faculty of Civil Engineering, Transportation Engineering and Architecture, Maribor, Slovenia
}

Timber-frame panel buildings have a very specific composition where the main challenge represent mechanical fasteners, which are unable to provide a fully rigid connection. The stiffness of the timber-framed walls is thus largely dependent on various factors that influences its stiffness, such as the bending and the shear flexibility of the composite wall element, the flexibility of the fasteners between the timber frame and the sheathing board along with the flexibility of the tensile and compressive support. Despite the fact that these contributions to the stiffness of the timber-framed walls are not negligible, they are not considered in Eurocode 5 standard for design of timber structures. The current paper analyses the contribution of the tensile support and presents the experimental and analytical study of inter-storey hold-down connections in timber-framed panel construction system. Experimental tests are performed for two different hold-down connections appropriate for connecting timber-framed walls from the upper floor through the ceiling to the timber-framed-walls of the lower floor. Experimental results show that hold-down connections do not provide a rigid support conditions for the timber-framed walls and that their flexibility should be taken into account when calculating the overall horizontal stiffness of the timber-framed walls. Therefore, an analytical expression for determination of the stiffness of the hold-down is suggested for the hold-down connection with perforated strap. The formula can be used for analytical calculation of the stiffness of the timber-framed walls by taking into account the stiffness of the tensile support when a tested hold-down anchor is used.

Key words: Timber-frame panel structures, Timber-framed walls, Hold-down connections, Perforated strap, Angle brackets, Experimental study, Analytical expression, Stiffness

\section{INTRODUCTION}

Timber-frame panel construction system is one of the most widely used building system in timber construction in Europe. It originates from the American balloon-frame and platform-frame construction systems whose advantage is provedin factory prefabrication of the building elements assuring the so called "ideal weather conditions" where all building elements and details are carefully designed and precisely manufactured in the factory in accordance with work plans allowing contacts to align perfectly.

Due to its specific composition, timber-frame panel buildingsare very difficult to model. The main challenges are mechanical fasteners, which are unable to provide a fully rigid connection. The problem occurs when non-regular structures according to Eurocode 8 [1] appear, requiring more accurate analysis for lateral force distribution, as generation of the 3D model and use of a modal analysis. An example of a simple mathematical model appropriate for 3D-modelling of timber-framed wallsusing a braced frame with one fictive diagonal is presented in Pintarič and Premrov [2] and an upgradeof the developed model in Vogrinec, Premrov and KozemŠilih [3]. The model employs a simple analytical calculation of the stiffness of the timber-framed wall embedded in the calculation of the fictive diagonal diameter. On the other hand, the presented model is simultaneously able to encompass the influence of the stiffness of the sheathing material, the influence of the flexibility of the fasteners in the connecting plane between the timber frame and the sheathing board, the influence of flexibility of the tensile and compressive support and the influence of the door and window openings. Different analytical formulas for calculation of the stiffness of the timber-framed walls with the same analogy with summing deformations of the sheathing board, mechanical fasteners, timber frame and tensile and compressive support can also be found in Kessel [4], Casagrande et. al [5, 6], Sartori [7] and Hoekstra [8].Although the importance of including different contributions to the overall deformation of the timber-framed wall is addressed by different authors, the stiffness calculation of the timber-framed walls and the influence of the openings is not considered in the standard Eurocode 5 [9]. This article focuses on one of the contributions that influences the stiffness of the timber-framed wall and the building itself: the influence of the flexibility of the inter-storey hold-down connections. Even though the problem is discussed by different authors, only few experimental data and appropriate analytical formulas for the stiffness calculation of the hold-down anchor are available in the literature. Hence, the presented analysis deals with the first experimental test of inter-storey holddown connections which results in an analytical expression for one type of the connection. 


\section{TIMBER-FRAMED WALLS ANCHORING}

The required stability and load-bearing capacity of the timber-frame panel buildings in vertical and horizontal direction is attained with timber-framed walls, roof or floor diaphragms and the appropriate anchorage of the timber-framed wall elements. In fact, as written in Prion and Lam [10], horizontal roof and floor diaphragms are designed to distribute lateral loads to shear walls, which in turn carry this loads to the foundation. In timber-frame panel structures, the vertical bracing elements for carrying horizontal forces to the foundations are timber-framed walls. Their elements consist of a timber frame and single-sided or two-sided sheathing boards, attached to the timber frame with mechanical fasteners (usually staples). They can be produced as single-panel systems (Figure 1a) or as recently more commonly used macro-panel systems (Figure 1b). The timber frame is constituted by three timber studs and two timber plates (top and bottom) with the thermal insulation placed between timber elements as can be seen in Figure 1a. Additionally, different types of boards can be used as sheathing material. In Europe, the most commonly used types of boards are fibre-plaster boards (FPB) and oriented strand boards (OSB). Besides the fire safety function (fibre-plaster boards), their primary purpose is to ensure the horizontal stability of the building if the appropriate fastening to the timber frame is made. Their load-bearing capacity differs in the type of a used sheathing board. Premrov and Dobrila [11] present a numerical study,analysing the influence of OSB and fibre-plaster boards (FPB) on the racking resistance of timber-framed wall elements. The results of the developed semi-analytical model evidently demonstrate higher racking stiffness of the wall elements with FPB, while the racking resistance proves to be evidently higher in the case of using OSB boards. The authors indicate an important dilemma of using the best sheathing board with regard to the height and location of the building and recommend using OSB sheathing boards instead of fibre-plaster boards in extremely windy or seismic areas.

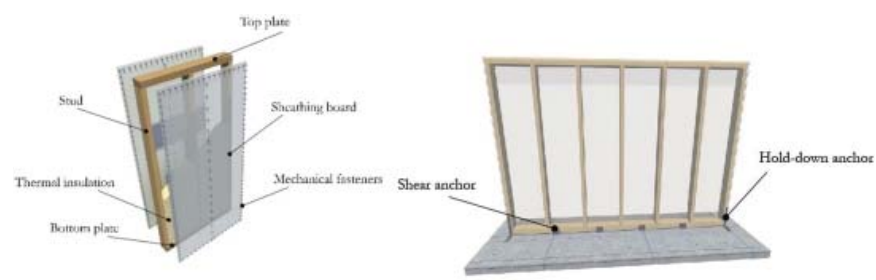

Figure 1: a) Composition of a single-panel wall element b) anchoring of the macro-panel timber-framed wall with shear and hold-down anchors to the foundations

The horizontal load transfers from upper to lower floor and to foundations, and the prevention fromwall overturning is achieved with appropriate anchoring of the wall to the ground. These hold-down forces, needed to maintain equilibrium, can be provided either through vertical loads from upper storeys or the roof, or they can come from a hold-down device attached to the vertical end stud (Prion and Lam [10]). In general, two different types of anchors are used for anchoring such a timber-framed wall. Shear anchors are used for shear forces appearing at the bottom of the wall and for sliding prevention, as well as for tension or hold-down forces and for the prevention of uplift of the wall hold-down anchors, as shown in Figure $1 \mathrm{~b}$.

Faherty and Williamson [12] claim that static equilibrium of the timber-framed wall requires the wall having a tension anchorage at the uplifting end. In practice, such an anchorage is needed at each end of the wall, since horizontal load can be imposed in either direction of the wall. As can be seen in Figure 2,tensile and shear forces are transmitted through the anchors, caused by the horizontal forces on the wall elements.

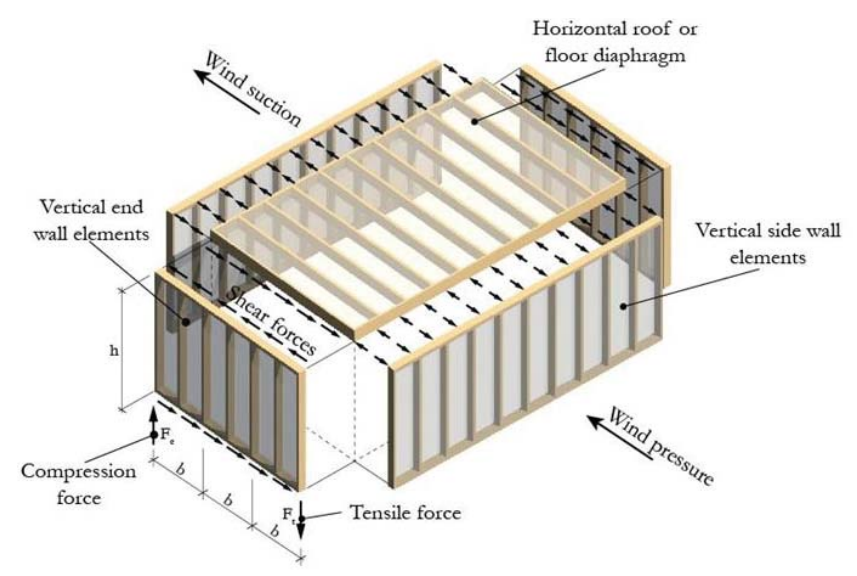

Figure 2: Load transfer between roofffloor diaphragms and wall elements

An anchor is usually a steel element (angle bracket, tape or plate) fastened with mechanical fasteners (typically nails) to the timber frame and with a screw to the concrete slab or on the ceiling or through the ceiling connection to the wall below. According to the purpose of use, we distinguish (i) anchors for anchoring the wall to the concrete slab and (ii) anchors for anchoring the wallsfromthe upper floor to the walls of the lower floor or to the ceiling. At the same time, we distinguish (a) hold-down or tensile anchorsused to transmit tensile forces and (b) shear anchors used to transmit shear forces. In praxis, different types of wall anchoring can appear. Some examples of European types of anchoring are shown in Figure 3 for anchors used foranchoring the wall to the concrete slab and in Figure 4 for anchors used foranchoring the walls from the upper floor to the walls of the lower floor or to the ceiling. Some other types of anchoring used in the world, such as anchoring through the bottom plate of the wall, are not appropriate for European timber-frame panel structures if factory prefabrication of the elements is used. This type of anchoring requires thewall to stay opened until the anchoring is done at the building site. 


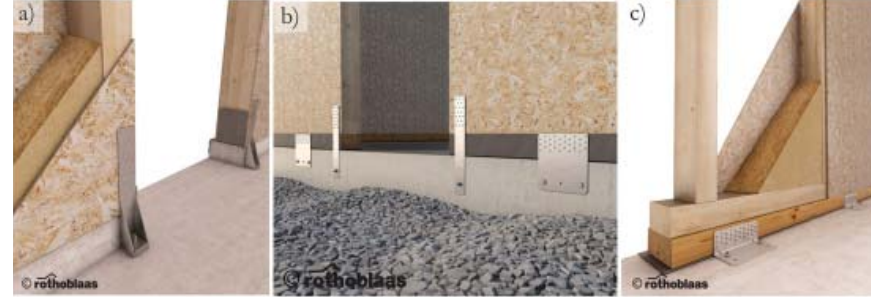

Figure 3: Examples of timber-framed walls anchoring to the concrete slab with a) angle brackets for tensile loads, b) straps for tensile loads and plates for shear loads c) angle brackets for shear loads (Crothoblaas)

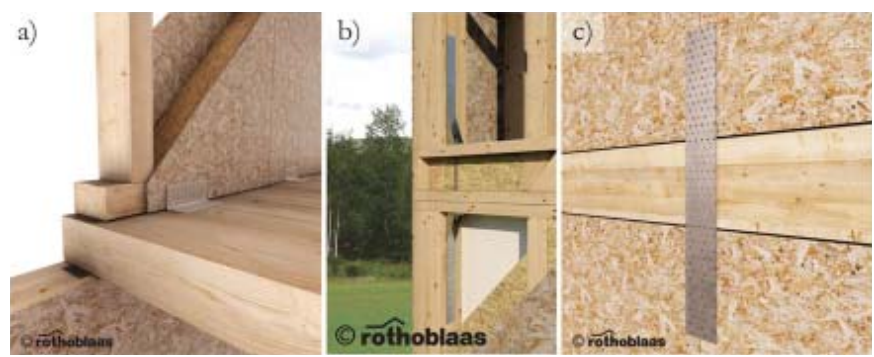

Figure 4: Examples of timber-framed walls anchoring to the ceiling and to the lower floor with a) angle brackets for shear forces, b) angle brackets for tensile forces, $c$ )

a perforated strap for tensile forces (Crothoblaas)

As can be seen above, anchoring of the wall elementsplays an important role when designing timber-framed walls. Hereafter we will focus on the influence of the hold-down anchors on the behaviour of timber-framed walls. Besides their role of preventing uplift of the wall and ensuring the equilibrium,their flexibility has an important impact on the overall horizontal stiffness of the timber-framed wall. The reason lies in the fact that hold-down anchors do not provide totally rigid connection of the timber-framed wall with the ground and therefore some additional displacement of the wall appears on account of the flexibility of the hold-down anchors. Regarding typical wall configuration, Casagrande et al. [5] determine the average percentage of deformation due to each single contribution (sheathing-to-framing connection, rigid-body translation, rigid-body rocking, sheathing panel) for timber-framed and CLT walls. Obviously, timber-framed wall deformation is mostly made by the sheathing-to-framing connection and the hold-down connections.

Different types of connection systems for shear and hold-down anchoring of the timber-framed wallsto the foundations are experimentally investigated in order to derive their stiffness and strength parameters in Tomasi and Sartori [13]. Authors tested different shear and holddown angle brackets and suggested several improved shear anchors. Moreover, different hold-down angle brackets appropriate for the anchoring on concrete plate were investigatedfor hold-down anchors. Almost all of them showed similar stiffness values and only one type of anchor showed three times higher values of stiffness.
The authors also pointed to the fact that Eurocode 5 [9] does not provide a suitable formula for calculating the strength and stiffness of the hold-down anchor. Besides the deformation resulting from nailed connection, authors suggested to include two further contributions when determining the stiffness of the hold-down anchor: local deformation of the base steel plate and the elongation of the vertical steel flange. Authors also showed that in the case of OSB plates, where the anchors are not directly attached to the timber stud (as in case of fibre-plaster sheathing boards) but through the sheathing board, the interposition of the OSB does not affect the behaviour of the connections and the OSB plate can be ignored when calculating the bearing capacity of a hold-down anchor.

Explanations forthe anchoring of thetimber-framed walls, including the installation of the anchors, and experimental studies are also available in Kessel and Polatschek [14].They experimentally tested perforated steel plates with different dimensions and number of nails which can be used for anchoring the timber-framed wall to the ground, and proposed an analytical expression for the stiffness of the tested hold-down anchor. The stiffness of the anchor in vertical direction $\mathrm{Kt}$ is expressed as the sum of the stiffness of the nails in the form of:

$K_{t}=n_{a}{ }^{*} k$

where $n_{a}$ is the number of fasteners in the steel-to-timber connection and $K$ is the slip modulus per shear plane per fastener. A simple analytical expression supported by a numerical example for hold-down anchor suitable for anchoring to the foundations is also proposed in zur Kammer [15], where the deformation of the tensile anchor is simply calculated as the sum of deformations resulting from:

- deformation of the fasteners between the tensile anchor and the timber stud,

- elongation of the anchor,

- flexure of the bottom plate of the anchor,

- elongation of the bolt anchor (where the connection between the bolt anchor and the concreteis not taken into account).

An analytical expression for hold-down anchors suitable for anchoring to the foundation is also discussed in Hoekstra [8], where the calculation method takes into account the stiffness of the steel and timber section, the stiffness of the fasteners, hole-clearance and the actual load level. The derived analytical expression is compared with experimental test available in the literature.

Consequently, the experimental studies and the analytical expressions are performed and derived for the hold-down anchors appropriate for the anchoring to the foundations. On the other hand, only few data can be found for the inter-storey hold-down connections where the timber-framed wall from upper floor is anchored through the ceiling to timber-framed wall in the lower floor (Figure 4b, c). According to zur Kammer [15] we can 
assume that the stiffness of the inter-storey connection with two angle brackets is half the size of the stiffness of the same angle bracket type used for anchoring to the concrete slab. Different hold-down anchoring details for connection of the timber-framed walls from the upper floor through the ceiling to the lower floor can be found for example in Kolb [16] and Holzrahmenbau [17]. An alternative approach for anchoring walls in multi-storey timber-framed buildings is discussed by Nelson, Patel and Arevalo [18],presenting a generic review of design issues of continuous tie-down systems for wood panel shear walls in multi-storey timber structures. This continuous tie-down system provides in comparison with traditional inter-storey hold-down connection an economical and structurally sound method of resisting overturning in multiple story wood framed buildings.

The following analysis describes an experimental and analytical studyof two ofthe most common types of inter-storey hold-down connections (hold-down connection with perforated strap or with two angle brackets) of the timber-framed walls. These two types are deliberately chosen because they allowthe direct connection of the timber-framed wall from the upper floor through the ceiling to the wall of the lower floor. Examples of this kind of anchoring can be seen in Figure 4b, c. In addition, analytical expression describing the stiffness of the investigated hold-down anchor is derived for the anchoring with perforated strap.

\section{EXPERIMENTAL AND ANALYTICAL STUDY}

\section{Test configuration}

Our experimental study tests two types of most often used inter-storeyhold-down connectionsin praxis, namely:

- Type A:perforated strap hold-down connection; hold-down connection where perforated strapis used and fastened to the timber studs in upper and lower floor with nails (Figure 4c)

- Type B:hold-down connection withtwoanglebrackets; hold-down connection where two angle brackets connected with threaded rod and fastened to the timber studs with nails are used (Figure 4b)

For each type of hold-down connection, one type of an anchor is experimentally investigated.Details for both types of anchoring are designed according to the details used in praxis in order to simulate as accurately as possible the actual anchoring situation. These details have also been used in Kolb [16] and Holzrahmenbau [17]. The test set-up for both types of hold-down connection is shown in Figure 5 for perforated strap connection and in Figure 6 for two angle brackets connection. Hold-down anchors are fixed directly to the timber studs without the interposition of the sheathing board (as this is the case when fibre-plaster boards are used). When OSB sheathing boards are used,in practice hold-down anchors are fixed to the timber-framed wall with the interposition of the OSB plate. But according to Tomasi and Sartori [13], the interposition of the OSB sheathing boardsdoes not affect the behaviour of the connections and the OSB plate can be ignored when calculating the bearing capacity of a hold-down anchor, as mentioned earlier.

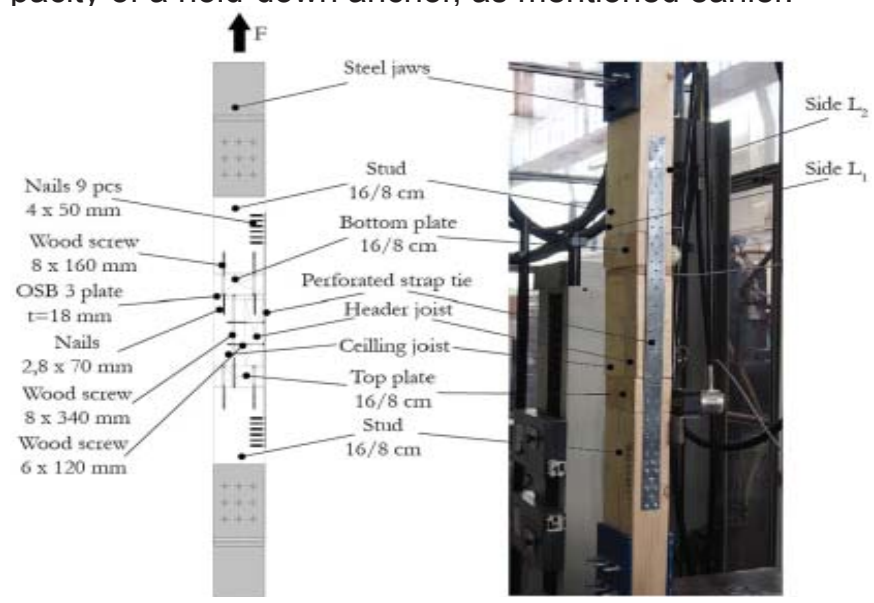

Figure 5: Experimental test set up for perforated strap hold-down connection (Type A)

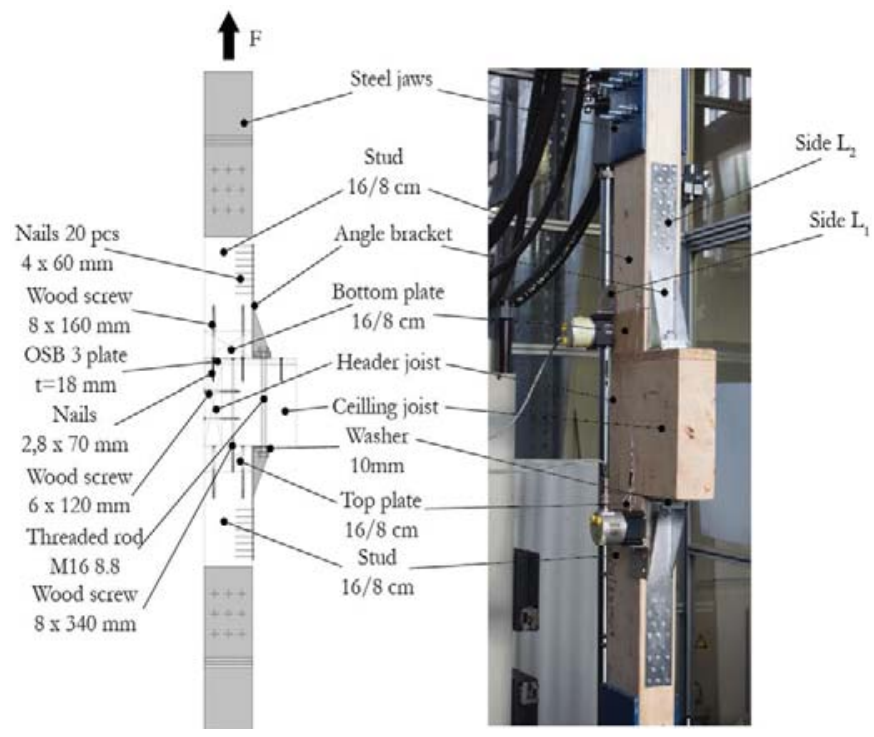

Figure 6: Experimental test set up for two angle brackets hold-down connection (Type B)

In the experimental study, 14 test specimens are tested; 7 test specimens for type A connection and 7 test specimens for type $B$, respectively. For each type of connection first test specimen is used for the determination of the Fest with the use of preliminary monotonic static test. Other 6 specimens of each type of connection are tested using the standard EN 26891 [19] and its loading procedure.

Test specimens for both types of anchoring are composed of wood elements of timber quality C24 which arerepresenting the timber stud and bottom plate of the upper wall, ceiling and header joist and timber stud and top plate of the wall below the ceiling. Timber studs are interconnected with perforated strap BAN204050 (Simpson Strong-Tie) for Type A connection and two angle brackets WHT 340 (Rothoblaas) connected with thread- 
ed rod M16 8.8 for Type B connection. Composition of test specimens is shown in Figure 5 for perforated strap connection and in Figure 6 for two angle brackets connection.

The displacements between timber studs of the upper and lower wall are measured separately on each side of the timber studs under the applied tensile load $\mathrm{F}$. The difference between displacements is caused by the eccentric anchoring of the tested hold-down anchors to the timber studs and the partial release of the rotation at the point where test specimens are clamped into device with
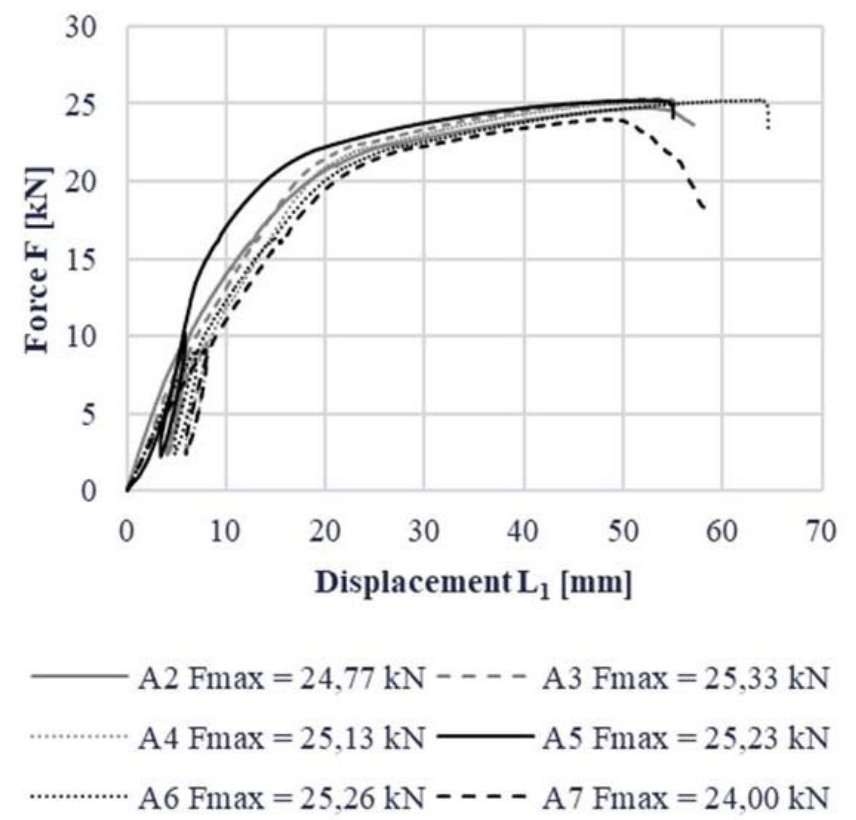

steel jaws. The measured displacements on the side of attached hold-down anchor is named L2 displacements and the displacement on the opposite side of the timber stud L1 displacement. Both measuring sides are shown in Figure 5 and Figure 6.

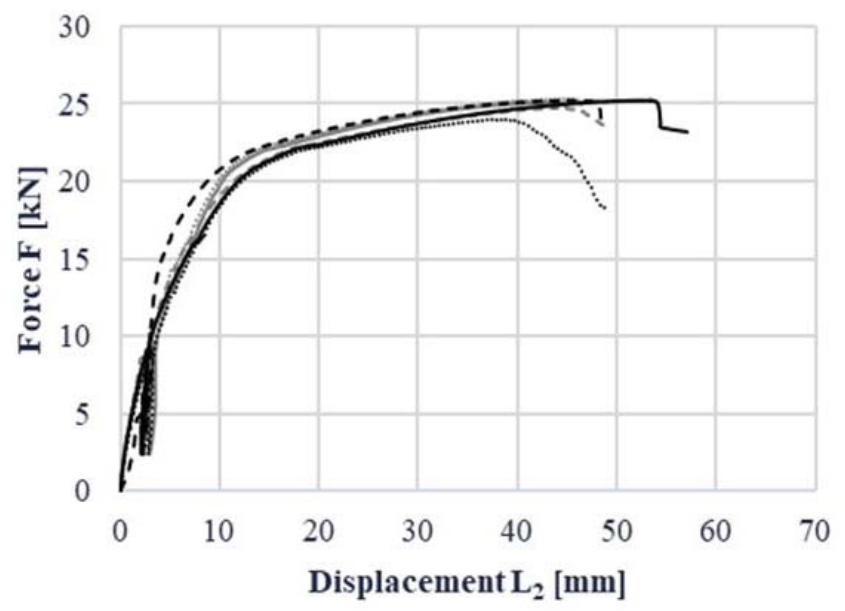

Figure 7: Force-displacement $\left(L_{1}, L_{2}\right)$ graphs for perforated straphold-down connection

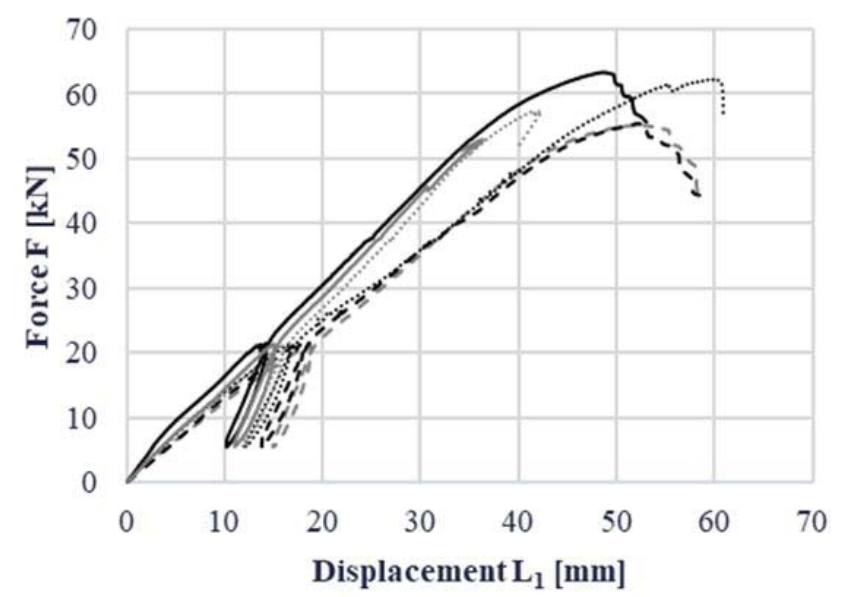

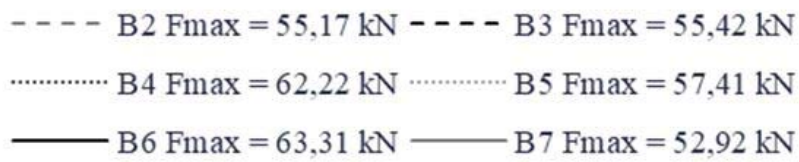
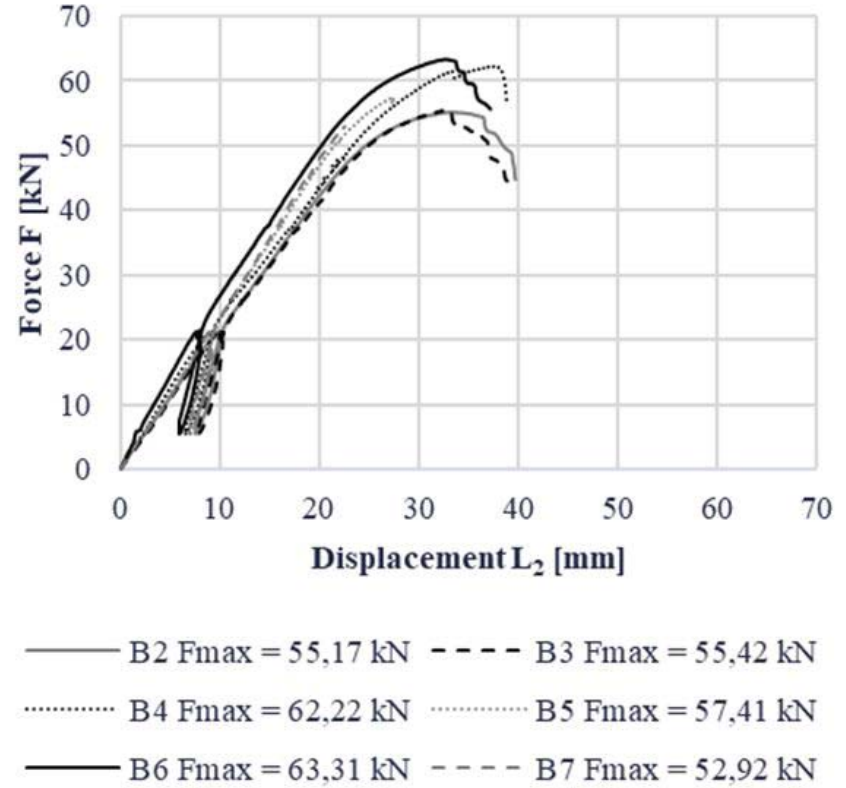

Figure 8: Force-displacement $\left(L_{1}, L_{2}\right)$ graphs for two angle brackets hold-down connection 


\section{Analysis of the results}

Figures 7 and 8 show experimental test results for both types of anchoring for all test specimens. Force-displacements graphs are shown separately for displacements $L_{1}$ and $L_{2}$ resulting from the eccentricity of the anchoring. It can be seen that displacements on the side $L_{2}$, where the anchor is attached, are smaller than on the sideL1, when the same load $F$ is applied. This is a logical consequence of the eccentrically fixing of the hold-down anchor.

The Figure 9 shows a force-displacement graph with mean values of displacements $L_{1}$ and $L_{2}$ from all test specimens for both types of connections. Dashed lines of the graph in Figure 9 represent the average values of the displacements $L_{1}$ and $L_{2}$ for each type of the connection. The higher load-bearing capacity of the anchor is achieved by using a hold-down connection with two angle brackets, whereas a higher stiffness of an anchor is achieved by using a perforated strap hold-down connection.

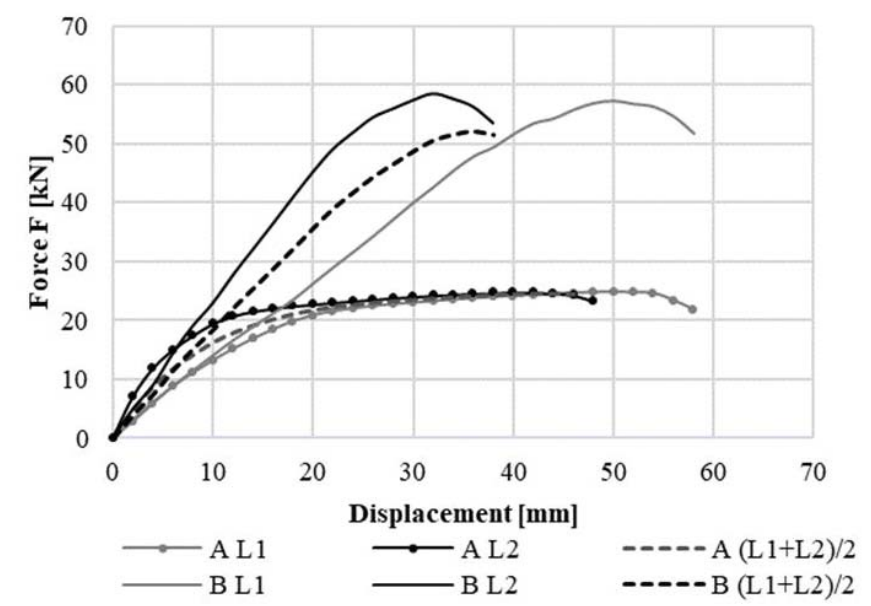

Figure 9: Force-displacement graph: comparison between average values of displacements for both types of connections

Tables 1 and 2 display an input data and measured values of $v_{01}, v_{02}, F_{\max }$ according to the standard EN 26891 [19] for all test samples. For both types of testedhold-down anchors, a stiffness $k_{\mathrm{s}}$ based on the test results is calculated according to EN 26891 [19] and is shown in Table 1 for perforated strap and inTable 2 for angle brackets for both measured displacements $L_{1}$ and $L_{2}$. Depending on the type of anchoringused,different failure mechanism occurred as can be seen from Tables 1 and 2 and in Figure 10 where different failure mechanisms of test specimens are shown. Two different types of failure occurred on the perforated strap; steel tape tearing and nails pulling are shown in Figure $10 \mathrm{a}, \mathrm{b}$. In the case of two angle brackets, failure of the tested connection occurred as a result ofnailspulling and tearing (Figure 10c) and in two cases failure developed in the timber stud as the consequence of the defects in the stud. The cause of a failure was the presence of the gnarls in the wood. At this point a high concentration of the tensile stresses perpendicu- lar to the grain occurred, which led to a rapid and brittle failure of the test specimen.
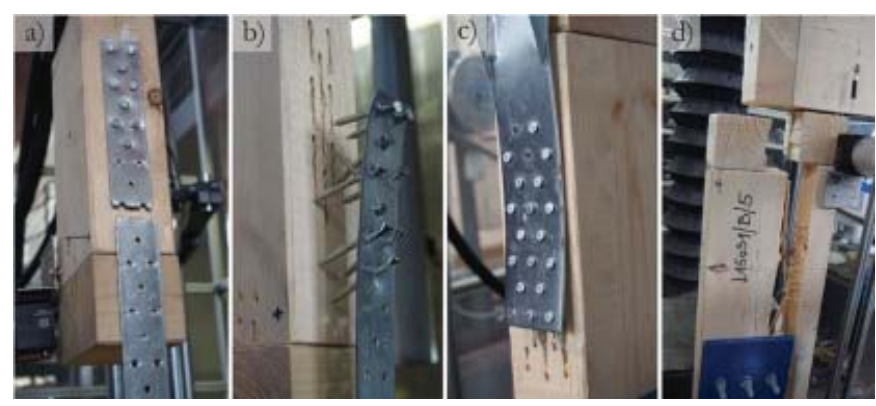

Figure 10: Failure mechanisms for both types of connections: a) steel tape tearing, b) nails pulling, c) nails pulling and tearing, d) timber stud failure

The importance of the contribution of the hold-down anchors on the stiffness of the timber-framed wall has already been highlighted in Casagrande et al. [5] where the average percentage of deformation due to each single contribution is shown for timber-framed walls. The value of the hold-down stiffness taken into the calculation was $5000 \mathrm{~N} / \mathrm{mm}$. The experimental tests of the hold-down anchors suitable for anchoring to the foundations has also been performed in Tomasi and Sartori [13] where almost all of tested types of hold-down anchors showed similar values of the stiffness (around $3000 \mathrm{~N} / \mathrm{mm}$ ). As can be seen from the experimental resultsin Tables 1 and 2, the stiffnessks of the tested inter-storey hold-down anchors is even smaller than the stiffness of the hold-down anchors used for anchoring to the foundationsmentioned above. As the flexibility of the inter-storey hold-down anchor is higher than the flexibility of the hold-down anchor used for anchoring to the foundations, its contribution to the horizontal stiffness of the timber-framed wall would be even higher than the contribution of the hold-down anchor used for anchoring to the foundations. The importance of including the contribution of the flexibility of the hold-down anchors to the overall horizontal stiffness of the timber-framed wall thus has even greater significance in the case of inter-storey hold-down connections. As already emphasized in Tomasi and Sartori [13],an analytical expression which adequately describes the stiffness of the hold-down anchors is needed not only for hold-down anchors appropriate for anchoring to the foundations but also in the case of inter-storey holddown connections.

\section{Derivation of the analytical expression for the stiffness of the perforated strap}

Analytical expression for the stiffness of a hold-down connection with perforated strapis derived by summing different contributions to the overall stiffness of the perforated strap in vertical direction. The total flexibility of the perforated strap and consequently its stiffness $K_{\text {typea }}$ is equal to the sum of: (i) contribution of the 
flexibility of the nails fastened in the upper and lower stud of the timber-framed wall and (ii) contribution as a result of elongation of the perforated steel tape in the form of:

$$
1 / K_{\text {TypeA }}=1 / K_{\text {nails, up }}+1 / K_{\text {nails, down }}+1 / K_{\text {steel }}
$$

where $K_{\text {nails, up }}$ is the stiffness of the nails fastened to stud in the timber-framed wall of the upper floor, $K_{\text {nails, down }}$ is the stiffness of the nails fastened to stud in the timber-framed wall of the lower floor and $K_{\text {steel }}$ is the stiffness of the perforated steel tape.

It should be mentioned that Eurocode 5 [9] does not include any analytical expression for calculating the stiffness of the hold-down anchor, but it provides the formulas for calculating the joint slip with the help of the slip modulus $K_{\text {ser }}$ per shear plane per fastener. For nails without pre-drilling, the slip modulus $K_{\text {ser }}$ per shear plane per fastener is calculated according to Eurocode 5 [9] as:

$$
K_{s e r}=\left(\rho_{m}^{1.5 *} d^{0.8}\right) / 30
$$

where $d$ is the diameter of the nail in $\mathrm{mm}$ and $\rho_{m}$ mean density of the timber member in $\mathrm{kg} / \mathrm{m} 3$. The stiffness of the n-nails $K_{\text {nails }}$ can now be calculated as the product of number of nails $n_{\text {nails }}$ and the slip modulus $K_{\text {ser }}$ per shear plane per fastener in the form of:

$$
K_{\text {nails }}=n_{\text {nails }}{ }^{*} K_{\text {ser }}
$$

\begin{tabular}{|c|c|c|c|c|c|c|c|}
\hline \multicolumn{2}{|c|}{ Sample } & A2 & A3 & A4 & A5 & A6 & A7 \\
\hline \multicolumn{2}{|c|}{ Failure mechanism } & Nails pulling & Tape tearing & Tape tearing & Tape tearing & Tape tearing & Nails pulling \\
\hline \multicolumn{2}{|c|}{ Type of connection } & $\begin{array}{l}\text { perforated } \\
\text { strap }\end{array}$ & $\begin{array}{l}\text { perforated } \\
\text { strap }\end{array}$ & $\begin{array}{l}\text { perforated } \\
\text { strap }\end{array}$ & $\begin{array}{l}\text { perforated } \\
\text { strap }\end{array}$ & $\begin{array}{l}\text { perforated } \\
\text { strap }\end{array}$ & $\begin{array}{l}\text { perforated } \\
\text { strap }\end{array}$ \\
\hline \multicolumn{2}{|c|}{ Type of the perforated strap } & BAN204050 & BAN204050 & BAN204050 & BAN204050 & BAN204050 & BAN204050 \\
\hline \multicolumn{2}{|c|}{ Manufacturer } & $\begin{array}{l}\text { Simpson } \\
\text { Strong-Tie }\end{array}$ & $\begin{array}{l}\text { Simpson } \\
\text { Strong-Tie }\end{array}$ & $\begin{array}{l}\text { Simpson } \\
\text { Strong-Tie }\end{array}$ & $\begin{array}{l}\text { Simpson } \\
\text { Strong-Tie }\end{array}$ & $\begin{array}{l}\text { Simpson } \\
\text { Strong-Tie }\end{array}$ & $\begin{array}{l}\text { Simpson } \\
\text { Strong-Tie }\end{array}$ \\
\hline \multicolumn{2}{|c|}{ Thickness of the tape [mm] } & 2.0 & 2.0 & 2.0 & 2.0 & 2.0 & 2.0 \\
\hline \multicolumn{2}{|c|}{ Width of the tape [mm] } & 40 & 40 & 40 & 40 & 40 & 40 \\
\hline \multicolumn{2}{|c|}{ Length of the tape [mm] } & 860 & 860 & 860 & 860 & 860 & 860 \\
\hline \multicolumn{2}{|c|}{ Nails } & $4.0 \times 50 \mathrm{~mm}$ & $4.0 \times 50 \mathrm{~mm}$ & $4.0 \times 50 \mathrm{~mm}$ & $4.0 \times 50 \mathrm{~mm}$ & $4.0 \times 50 \mathrm{~mm}$ & $4.0 \times 50 \mathrm{~mm}$ \\
\hline \multicolumn{2}{|c|}{$\begin{array}{l}\text { The number of nails per stud } \\
\text { [pcs] }\end{array}$} & 9 & 9 & 9 & 9 & 9 & 9 \\
\hline \multicolumn{2}{|c|}{ Diameter of the nail hole [mm] } & 5.0 & 5.0 & 5.0 & 5.0 & 5.0 & 5.0 \\
\hline \multicolumn{2}{|c|}{$\mathrm{F}_{\max }[\mathrm{N}]$} & 24768 & 25333 & 25132 & 25229 & 252622 & 24005 \\
\hline \multirow{5}{*}{$\mathrm{L}_{1}$} & $\mathrm{v}_{01}[\mathrm{~mm}]$ & 1.22 & 1.81 & 1.94 & 2.47 & 1.84 & 1.87 \\
\hline & $\mathrm{v}_{04}[\mathrm{~mm}]$ & 6.21 & 7.15 & 8.59 & 5.83 & 7.88 & 8.56 \\
\hline & $\mathrm{v}_{\mathrm{i}, \mathrm{mod}}[\mathrm{mm}]$ & 6.66 & 7.12 & 8.86 & 4.49 & 8.07 & 9.05 \\
\hline & $\mathrm{k}_{\mathrm{s}}[\mathrm{N} / \mathrm{mm}]$ & 1488.09 & 1422.29 & 1134.66 & 2248.08 & 1252.69 & 1061.37 \\
\hline & $\mathrm{k}_{\mathrm{s}}[\mathrm{N} / \mathrm{mm}]$ & \multicolumn{6}{|c|}{1434.53} \\
\hline \multirow{5}{*}{$\mathrm{L}_{2}$} & $\mathrm{v}_{01}[\mathrm{~mm}]$ & 0.45 & 0.46 & 0.39 & 1.28 & 0.49 & 0.52 \\
\hline & $\mathrm{v}_{04}[\mathrm{~mm}]$ & 3.08 & 3.15 & 3.77 & 3.02 & 3.19 & 3.57 \\
\hline & $\mathrm{v}_{\mathrm{i}, \mathrm{mod}}[\mathrm{mm}]$ & 3.51 & 3.59 & 4.50 & 2.32 & 3.60 & 4.06 \\
\hline & $\mathrm{k}_{\mathrm{s}}[\mathrm{N} / \mathrm{mm}]$ & 2819.56 & 2823.70 & 2232.10 & 4345.71 & 2805.18 & 2362.56 \\
\hline & $\mathrm{k}_{\mathrm{s}}[\mathrm{N} / \mathrm{mm}]$ & \multicolumn{6}{|c|}{2898.30} \\
\hline
\end{tabular}

Table 1: Perforated strap (type A) test results 
Table 2: Two angle brackets (type B) test results

\begin{tabular}{|c|c|c|c|c|c|c|c|}
\hline \multicolumn{2}{|c|}{ Sample } & B2 & B3 & B4 & B5 & B6 & B7 \\
\hline \multicolumn{2}{|c|}{ Failure mechanism } & $\begin{array}{l}\text { Nails pulling } \\
\text { and tearing }\end{array}$ & $\begin{array}{l}\text { Nails pulling } \\
\text { and tearing }\end{array}$ & $\begin{array}{l}\text { Nails pulling } \\
\text { and tearing }\end{array}$ & $\begin{array}{l}\text { Timber stud } \\
\text { failure }\end{array}$ & $\begin{array}{l}\text { Nails pulling } \\
\text { and tearing }\end{array}$ & $\begin{array}{c}\text { Timber stud } \\
\text { failure }\end{array}$ \\
\hline \multicolumn{2}{|c|}{ Type of connection } & $\begin{array}{c}\text { angle } \\
\text { brackets }\end{array}$ & $\begin{array}{c}\text { angle } \\
\text { brackets }\end{array}$ & $\begin{array}{c}\text { angle } \\
\text { brackets }\end{array}$ & $\begin{array}{c}\text { angle } \\
\text { brackets }\end{array}$ & $\begin{array}{c}\text { angle } \\
\text { brackets }\end{array}$ & $\begin{array}{c}\text { angle } \\
\text { brackets }\end{array}$ \\
\hline \multicolumn{2}{|c|}{ Type of the angle bracket } & WHT 340 & WHT 340 & WHT 340 & WHT 340 & WHT 340 & WHT 340 \\
\hline \multicolumn{2}{|c|}{ Manufacturer } & Rothoblaas & Rothoblaas & Rothoblaas & Rothoblaas & Rothoblaas & Rothoblaas \\
\hline \multicolumn{2}{|c|}{ Thickness of the anchor [mm] } & 3.0 & 3.0 & 3.0 & 3.0 & 3.0 & 3.0 \\
\hline \multicolumn{2}{|c|}{ Width of the anchor [mm] } & 60 & 60 & 60 & 60 & 60 & 60 \\
\hline \multicolumn{2}{|c|}{ Length of the anchor [mm] } & 340 & 340 & 340 & 340 & 340 & 340 \\
\hline \multicolumn{2}{|c|}{ Threaded rod } & M16 8.8 & M16 8.8 & M16 8.8 & M16 8.8 & M16 8.8 & M16 8.8 \\
\hline \multicolumn{2}{|c|}{ Nails } & $4.0 \times 60 \mathrm{~mm}$ & $4.0 \times 60 \mathrm{~mm}$ & $4.0 \times 60 \mathrm{~mm}$ & $4.0 \times 60 \mathrm{~mm}$ & $4.0 \times 60 \mathrm{~mm}$ & $4.0 \times 60 \mathrm{~mm}$ \\
\hline \multicolumn{2}{|c|}{$\begin{array}{l}\text { The number of nails per } \\
\text { anchor [pcs] }\end{array}$} & 20 & 20 & 20 & 20 & 20 & 20 \\
\hline \multicolumn{2}{|c|}{ Diameter of the nail hole [mm] } & 5.0 & 5.0 & 5.0 & 5.0 & 5.0 & 5.0 \\
\hline \multicolumn{2}{|c|}{$\mathrm{F}_{\max }[\mathrm{N}]$} & 55175 & 55420 & 62217 & 57407 & 63311 & 52920 \\
\hline \multirow{5}{*}{$\mathrm{L}_{1}$} & $\mathrm{v}_{01}[\mathrm{~mm}]$ & 4.20 & 4.34 & 4.19 & 3.83 & 3.06 & 3.46 \\
\hline & $\mathrm{v}_{04}[\mathrm{~mm}]$ & 19.77 & 18.95 & 19.45 & 17.35 & 16.49 & 15.03 \\
\hline & $\mathrm{v}_{\mathrm{i}, \bmod }[\mathrm{mm}]$ & 20.76 & 19.48 & 20.34 & 18.03 & 17.92 & 15.44 \\
\hline & $\mathrm{k}_{\mathrm{s}}[\mathrm{N} / \mathrm{mm}]$ & 1063.36 & 1137.98 & 1223.55 & 1273.79 & 1413.36 & 1371.37 \\
\hline & $k_{s}[N / m m]$ & \multicolumn{6}{|c|}{1247.24} \\
\hline \multirow{5}{*}{$\mathrm{L}_{2}$} & $\mathrm{v}_{01}[\mathrm{~mm}]$ & 2.50 & 2.65 & 2.64 & 2.32 & 2.09 & 2.40 \\
\hline & $\mathrm{v}_{04}[\mathrm{~mm}]$ & 10.46 & 10.68 & 10.52 & 9.91 & 9.39 & 9.14 \\
\hline & $\mathrm{v}_{\mathrm{i}, \bmod }[\mathrm{mm}]$ & 10.61 & 10.71 & 10.51 & 10.13 & 9.74 & 8.99 \\
\hline & $\mathrm{k}_{\mathrm{s}}[\mathrm{N} / \mathrm{mm}]$ & 2079.22 & 2068.92 & 2368.41 & 2266.52 & 2600.96 & 2354.34 \\
\hline & $\mathrm{k}_{\mathrm{s}}[\mathrm{N} / \mathrm{mm}]$ & \multicolumn{6}{|c|}{2289.73} \\
\hline
\end{tabular}

The calculation of stiffness of the perforated steel tape takes into account the cross-section of the tape without the holes for the nailsAs, neto.In Hoekstra [8], detailed analysis of the force distribution between fasteners exposes linear hold-down force distribution over the fasteners which is valid for the elastic part of the force-displacement diagram of the hold-down. Accordingly, the whole length of the steel tape is not considered in the calculation. The reduced length of the steel tape taken into account $L_{s}$ is now calculated as the actual length of the steel tape reduced by the value of half the length of the tape section, where nails are attached.

The stiffness of the steel tape $K_{\text {steel }}$ is now written in the form of:
$K_{\text {steel }}=E_{s}{ }^{*} A_{s, \text { neto }} / L_{s}$

where $E_{s}$ is the modulus of elasticity of the steel tape, $A_{s, \text { neto }}$ net cross-section of the steel tape and $L_{s}$ reduced length of the steel tape.

According to the formulas (2-5), an analytical value of the stiffness of the perforated strap is calculated. $2 \times 9$ pieces of nails dimensions of $4,0 \mathrm{~mm} \times 50 \mathrm{~mm}$ are used for the hold-down connection with perforated strap. The thickness of the steel tape is $t=2 \mathrm{~mm}$, width of the tape is $b_{\text {tape }}=40 \mathrm{~mm}$ and length $L=860 \mathrm{~mm}$. Diameter of the nails hole is $5 \mathrm{~mm}$ with 2 holes in a row. Nails are fastened to the timber stud in the length of $110 \mathrm{~mm}$ on each side. For timber studs wood quality of $\mathrm{C} 24$ according to EN 338 [20] is used with mean density of $\rho_{m}=420 \mathrm{~kg} / \mathrm{m}^{3}$. 
Stiffness of the nails $K_{\text {nails }}$ is now calculated according to equations $(3,4)$ as:

$\mathrm{K}_{\text {nails }}=\mathrm{n}_{\text {nails }} \cdot \frac{\rho_{\mathrm{m}}^{1,5} \cdot \mathrm{d}^{0,8}}{30}=9 \cdot \frac{420^{1,5} \cdot 4,0^{0,8}}{30}=7827,86 \frac{\mathrm{N}}{\mathrm{mm}}$

And stiffness of the steel tape according to equation (5) as:

$\mathrm{K}_{\mathrm{stelel}}=\frac{\mathrm{E}_{\mathrm{s}} \cdot \mathrm{A}_{\mathrm{s}, \text { neto }}}{\mathrm{L}_{\mathrm{s}}}=\frac{2,1 \cdot 10^{5} \frac{\mathrm{N}}{\mathrm{mm}^{2}} \cdot(2 \mathrm{~mm} \cdot(40 \mathrm{~mm}-2 \cdot 5 \mathrm{~mm}))}{860 \mathrm{~mm}-110 \mathrm{~mm}}=16800 \frac{\mathrm{N}}{\mathrm{mm}}(7)$

The analytically obtained stiffness of the perforated strap connection in the vertical direction is calculated according to equation (2) as:

$$
\mathrm{K}_{\text {type }}=\frac{1}{\frac{1}{7827,86}+\frac{1}{7827,86}+\frac{1}{16800}}=3174,39 \frac{\mathrm{N}}{\mathrm{mm}}
$$

\section{Comparison of the results}

Figure 11 shows a comparison between experimental tests results and analytical formula for the stiffness of the hold-down anchor where perforated strap is used. Analytically obtained stiffness of the perforated strap is $K_{\text {type } A}=3174,39 \mathrm{~N} / \mathrm{mm}$ and the experimental value for the stiffness of the perforated strap on the side $L_{2}$ where the strap is attached to the timber stud, is equal to $k_{s}=2898,30 \mathrm{~N} / \mathrm{mm}$. As can be seen from the stiffness comparison in Figure 11, analytically obtained values are about $10 \%$ higher than experimentally obtained values what makes a good agreement between experimental and analytical test results. In analytical calculations both contributions were included in stiffness calculation; the flexibility of the nails fastened in the upper and lower stud of the timber-framed wall and the elongation of the perforated steel tape. If only deformation of the nails were taken into account when calculating the stiffness of the perforated strap, this would lead to overestimation of the stiffness of the hold-down anchor.Consequently, similar conclusions were drawn in experimental tests for hold-down anchors suitable for anchoring to the foundationsby Tomasi and Sartori [13].The presented analytical formula for the stiffness of the perforated strap can be used with analytical formula for the horizontal stiffness of the timber-framed walls presented in Vogrinec, Premrov and KozemŠilih [3]. However, in order to use conclusions on different hold-down anchors, these connections need further numerical and experimental studies.

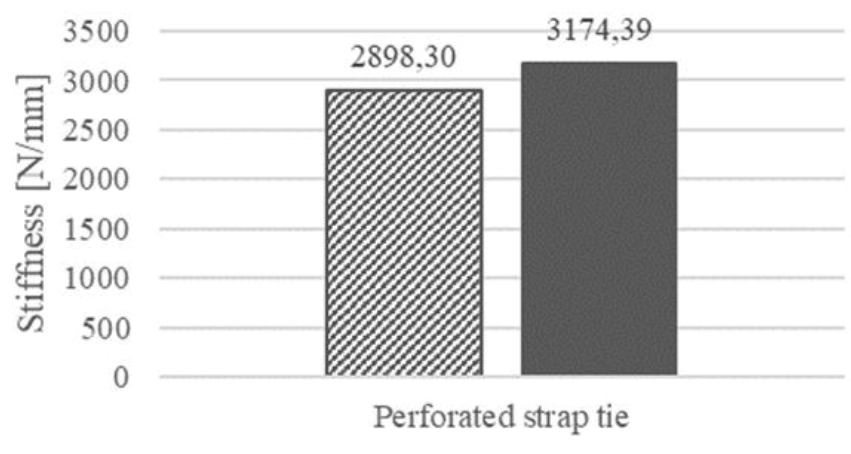

@Experimental Analytical

Figure 11: Comparison between the experimental and the analytically determined stiffness of the perforated strapconnection

\section{CONCLUSIONS}

Eurocode 5 [9] does not provide recommendationson calculation of the flexibility for the hold-down anchors and on inclusion of their contribution to the horizontal stiffness of the timber-framed walls and the building itself. The first experimental test of the hold-down and shear anchors for the connections between timber-framed walls and foundations performed in Tomasi and Sartori [13] and derived analytical procedure in Casagrande et al. [5] already highlighted the fact that the contribution of the hold-down anchor should be taken into account when calculating the stiffness of the timber-framed walls. The experimental study of the inter-storey hold-down connectionspresented in this article shows similar conclusions. The inter-storey hold-down connectionalso doesnot provide totally rigid support condition for the timber-framed walland its flexibility should be taken into account when calculating the stiffness of the timber-framed wall.In conclusion,the presented experimental results prove (Figure 9) that the load-carrying capacity and the stiffness of the resisting wall elements essentially depend on the type of the inter-storey connection and it is not negligible in the calculation of the stiffness of the timber-framed walls. In the presented experimental study,higher stiffness of the connection is obtained by using perforated strap, while higher load-carrying capacity is ensured with two angle brackets connection. Moreover, a good agreement between derived analytical formula and experimental results is achieved in the case of perforated strap.

The presented experimental studyis the starting point of the future studies of the inter-storey hold-down connections. However, additional experimental and numerical studies are needed for more general conclusions and appropriate derivation of analytical formulas. It would be of great importance to offerengineering practice the appropriate analytical formulas for different types of holddown connections. In addition, they should be included in European standards and should enable engineers to influence the stiffness and load-bearing capacity of the hold-down anchor and the building itself by simplevary- 
ing of the hold-down anchor type. Moreover, the influence of the inter-storey hold-down connections should be considered in the analysis of the entire timber-frame panel building under the influence of the horizontal forces. Therefore, the actual differences in the flexibility of the building and effect of the inter-storey hold-down anchoring on the distribution of the horizontal forces and horizontal displacements will be visible.

\section{ACKNOWLEDGEMENTS}

Operation part financed by the European Union, European Social Fund.

\section{REFERENCES}

1. European Committee for Standardization. (2005). Eurocode 8: Design of structures for earthquake resistance - Part 1: General rules, seismic actions and rules for buildings, EN 1998-1. Brussels.

2. Pintarič, K., \& Premrov, M. (2013). Mathematical modelling of timber-framed walls using fictive diagonal elements. Applied Mathematical Modelling, 37, 8051-8059. doi:10.1016/j.apm.2013.02.050

3. Vogrinec, K., Premrov, M., \& Kozem Šilih, E. (2016). Simplified modelling of timber-framed walls under lateral loads. Engineering structures, 111, 275-284. doi:10.1016/j.engstruct.2015.12.029

4. Kessel, M.H. (2004). Vereinfachte Berechnung von scheibenartig beanspruchten Tafeln. In H.J. Blaß, K.J.H. Ehlbeck, \& G. Steck (Eds.), Erläuterungen zu DIN. München: DGfH Innovations und Service $\mathrm{GmbH}$. 1052: 2004-08.

5. Casagrande, D., Rossi, S., Sartori, T., \& Tomasi, R. (2016). Proposal of an analytical procedure and a simplified numerical model for elastic response of single-storey timber shear-walls. Construction and Building Materials, 102, 1101-1112. doi:10.1016/j. conbuildmat.2014.12.114

6. Casagrande, D., Rossi, S., Sartori, T., \& Tomasi, R. (2012). Analytical and numerical analysis of timber framed shear walls. In World Conference on Timber Engineering. Auckland, New Zealand.

7. Sartori, T. (2012). Structural behavior of timber framed buildings. Dottorato di Ricerca in Ingegneria dei Sistemi Strutturali Civili e Meccanici XXV ciclo. Università degli Studi di Trento.

8. Hoekstra, T. (2012). Multi-storey timber-frame building. Delft: Delft University of Technology, Faculty of Civil Engineering and Geosciences. MSc Thesis.

9. European Committee for Standardization. (2004).
Eurocode 5: Design of timber structures - Part 1-1: General - Common rules and rules for buildings, EN 1995-1-1. Brussels.

10. Prion, H.G.L., \& Lam, F. (2003). Shear Walls and Diaphragms. In S. Thelandersson \& H.J. Larsen (Eds.), Timber engineering. (pp. 383-408). Chichester: John Wiley and Sons Ltd.

11. Premrov, M., \& Dobrila, P. (2012). Numerical analysis of sheathing boards influence on racking resistance of timber-frame walls. Advances in Engineering Software, 45(1), 21-27. doi:10.1016/j. advengsoft.2011.09.012

12. Faherty, K.F., \& Williamson, T.G. (1998). Wood Engineering and Construction Handbook, 3rd edition. New York: McGraw-Hill Publishing Company.

13. Tomasi, R., \& Sartori, T. (2013). Mechanical behaviour of connections between wood framed shear walls and foundations under monotonic and cyclic load. Construction and Building Materials, 44, 682690. doi:10.1016/j.conbuildmat.2013.02.055

14. Kessel, M.H., \& Polatschek, T.M. (2009). Verankerung von HolztafelnTagungsband 21. Hildesheimer Informationstag Holzbau (21. HITH). HAWK Hildesheim.

15. zur Kammer, T. (2006). Zum räumlichen Tragverhalten mehrgeschossiger Gebäude in Holztafelbauart. Braunschweig: Institut für Baukonstruktion und Holzbau der Technischen Universität Carolo-Wilhelmina zu Braunschweig.

16. Kolb, J. (2008). Systems in Timber Engineering. Basel: Birkhäuser.

17. Holzrahmenbau, Bewährtes Hausbau-System, 4. Auflage. (2011). Köln: Bruderverlag.

18. Nelson, R.F., Patel, S.T., \& Arevalo, R. (2003). Continuous tie-down systems for wood panel shear walls in multi story structures. Structure magazine, 1-16.

19. European Committee for Standardization. (1997). Timber structures - Joints made with mechanical fasteners - General principles for the determination of strength and deformation characteristics, EN 26891: 1997. Brussels.

20. European Committee for Standardization. (2009). Structural timber - Strength classes, EN 338: 2009. Brussels.

Paper submitted: 13.04.2018.

Paper accepted: 10.07.2018.

This is an open access article distributed under the CC $B Y-N C-N D 4.0$ terms and conditions. 